\title{
ENERGY POTENTIAL ASSESSMENT OF SOLAR AND WIND RESOURCES IN SYRIA
}

\author{
Viktor Elistratov ${ }^{1 *}$ Amer Ramadan $^{2}$ \\ ${ }^{1}$ Peter the Great Saint-Petersburg Polytechnic University, Russia \\ ${ }^{2}$ Peter the Great Saint-Petersburg Polytechnic University, Russia
}

The present paper aims to determine the energy potential of solar and wind resources in Syria. To achieve this goal, the first calculation method was developed for assessing the average total gross and technical potential of solar energy falling on a horizontal surface in Syria using electronic resource (Solar Atlas for the Mediterranean). The second calculation method was developed for estimating the average total gross and technical potential of wind energy in Syria using electronic resource (Global Wind Atlas). The results indicated: firstly, that the average total gross and technical potential of solar energy on a horizontal surface in Syria were estimated, respectively, 345406 TWh/year and 55265 TWh/year. Secondly, the average wind power at the height of $50 \mathrm{~m}$ and the average total gross potential of wind energy in Syria were estimated, respectively, 31,2 TW and 273533 TWh /year. Finally the average technical potential of wind energy using 1\%, 2\%, 3\%, 4\%, 5\% of the total area of Syria was estimated, respectively, 129 , $258,387,516,644$ TWh /year.

Key words: Solar, Wind, Energy, Method, Total gross potential, Technical potential, Electronic resource, Syria, Atlas

\section{INTRODUCTION}

The development of renewable energy sources over the past $15-20$ years is a very optimistic with the constant increase of the installed capacity and the share in the energy balance. Global electricity generation over the period 1973-2016 year increased from 6131 TWh to 25000 TWh [01]. In 2015 the share of energy produced from renewable energy sources amounted to $5534 \mathrm{TWh}$ or $23.1 \%$ ( $16 \%$ hydro and $7.1 \%$ non-hydro renewables) [02]. In 2016 Renewable power capacity (total, including hydro) reached more than $2000 \mathrm{GW}$ [03]. Solar and wind resources are considered the most promising kinds of renewable energy resources. Solar energy is used worldwide and is increasingly popular for generating electricity or heating and desalinating water. Solar power is generated in two main ways: (Photovoltaic (PV), concentrated solar power (CSP)). Solar PV leads the way in power generating capacity and is considered a cost-competitive source of new generation in many emerging markets across the world. Solar photovoltaic electricity production in 2015 amounted to 247 TWh, with net installed capacity reached $303 \mathrm{GW}$ and the share of solar PV energy in total domestic electricity generation amounted to $1 \%$ [01]. Wind energy technology has progressed significantly over the last two decades. The technology has been vastly improved and capital costs have come down to as low as $\$ 1000 / \mathrm{kW}$. At this level of capital costs, wind power is already economical at locations with fairly good wind resources. Wind electricity production in 2016 amounted to 960 TWh, with net installed capacity reached $487 \mathrm{GW}$ [04]. In 2015 the share of wind energy in total domestic electricity generation amounted to $3.4 \%$ [01].
Syria is a country in Western Asia, which has an area $185180 \mathrm{~km}^{2}$ and a high potential of renewable energy resources, particularly solar and wind. Electrical energy supply based on renewable energy can ensure the energy independence of the country. The average solar irradiation income on a horizontal surface in Syria estimates about $5 \mathrm{kWh} / \mathrm{m}^{2} /$ day, or $1800 \mathrm{kWh} / \mathrm{m}^{2} /$ year. It varies from $4.4 \mathrm{kWh} / \mathrm{m}^{2} /$ day in western mountainous areas to $5.2 \mathrm{kWh} / \mathrm{m}^{2} /$ day in desert areas. The number of hours of sunshine varies from 2820 to $3270 \mathrm{~h}$ [05]. In 1989, with financial support from UNDP (United Nations development Program) and in collaboration with the national Danish RISO laboratories was completed the wind Atlas of Syria, which contains information from 60 meteorological stations, covering most climatic zones in Syria. This information contains measurements for ten years $(1979-1989)$. According to wind atlas the wind map of Syria was carried out (see Figure 1). In this map, the country was divided into four wind zones. In the first zone (red zone) the wind speed is $(5-11.5) \mathrm{m} / \mathrm{s}$. This zone includes the central area, southern, west southern, and hilly coastal area [06]. In the period (2004-2006) and with corporation of German company Decon, promising wind sites were selected in the windiest zone (red zone in figure 1). Masts were installed in these sites and measurements of wind speed and direction were taken from (2004-2009) for constructing wind farms in the future. Each mast is equipped with the following sensors (anemometer at $40 \mathrm{~m}$ height, anemometer at $10 \mathrm{~m}$ height, wind vane at $40 \mathrm{~m}$ height, temperature sensor, and pressure sensor) and data are recorded in 10 min intervals as mean values (for all parameters) as well as maximum instantaneous values and standard deviation (for the wind speed) within the recording interval. Table 1 is shown information about promising wind sites (name, area, lo-

* Peter the Great Saint-Petersburg Polytechnic University, Polytechnicheskaya, 29, St. Petersburg 195251, Russia, 
cation, attitude, maximum and average wind speed at height 40m) [07, 08]. Annual and daily wind speed distributions in one of promising wind sites (Sindianah 1) are presented in Figures 2 [09]. In addition, site Tias in prov- ince Homs was studied in detail in [6], where wind energy potential was calculated at height $70 \mathrm{~m}$ and wind farm with capacity of $3.9 \mathrm{MW}$ was carried out using Windpro software.

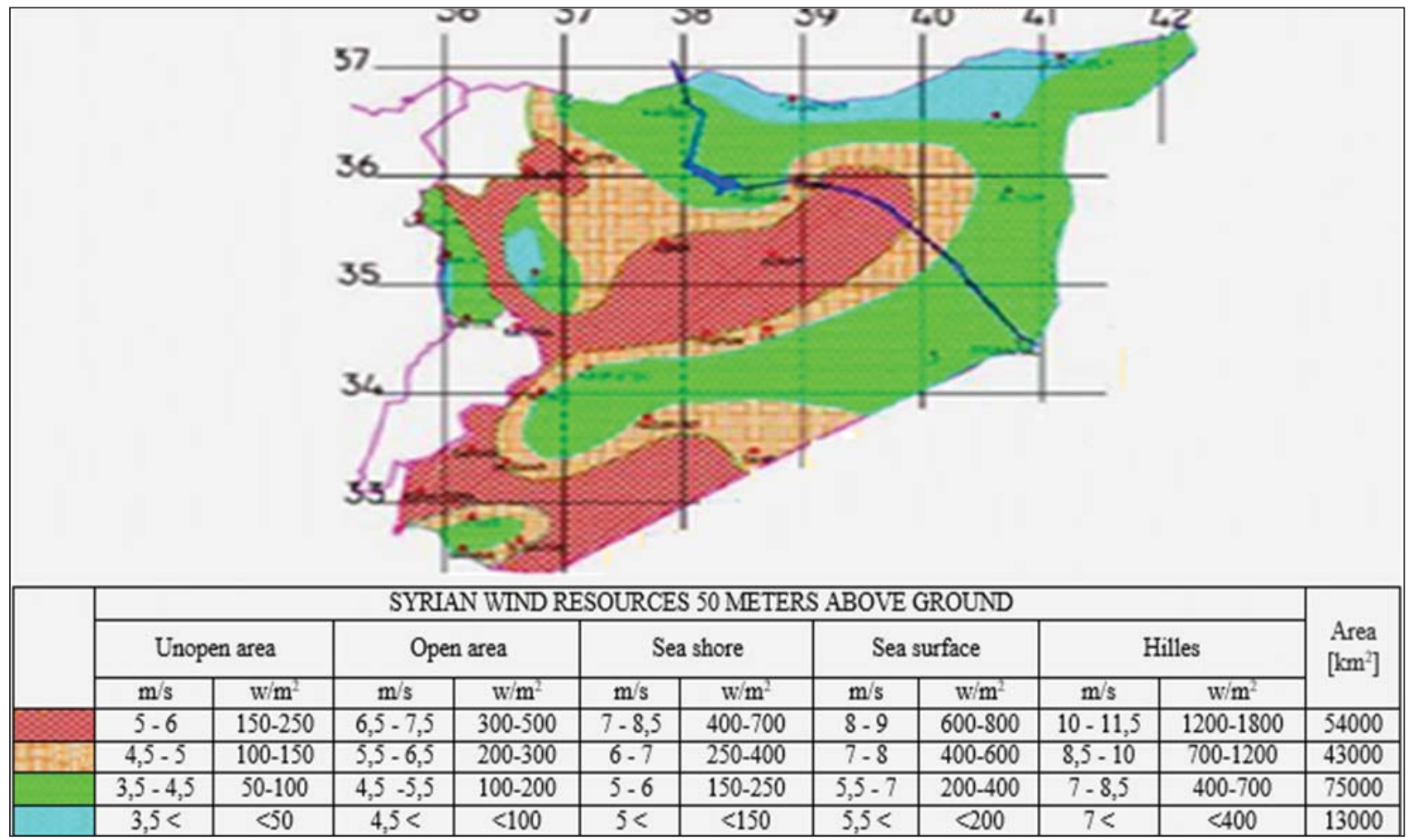

Figure 1: Wind map of Syria [06, 07]

It is very difficult from a wind map of Syria to estimate a one value which represents the average value of wind potential in all Syria, because there are 4 zones with 5 roughness class and power density changes within a specified range based on the zone and roughness class, therefore in this study calculation method was developed for assessing the average total gross and technical potential of wind energy in Syria using an electronic resource (Global Wind Atlas). On the other hand, assess- ment of the average solar potential of Syria and selection of area or zone which has the highest solar potential are important for recent and further photovoltaic applications in Syria, therefore the other method was developed for calculating the average total gross and technical potential of solar energy falling on a horizontal surface in Syria using an electronic resource (Solar Atlas for the Mediterranean).
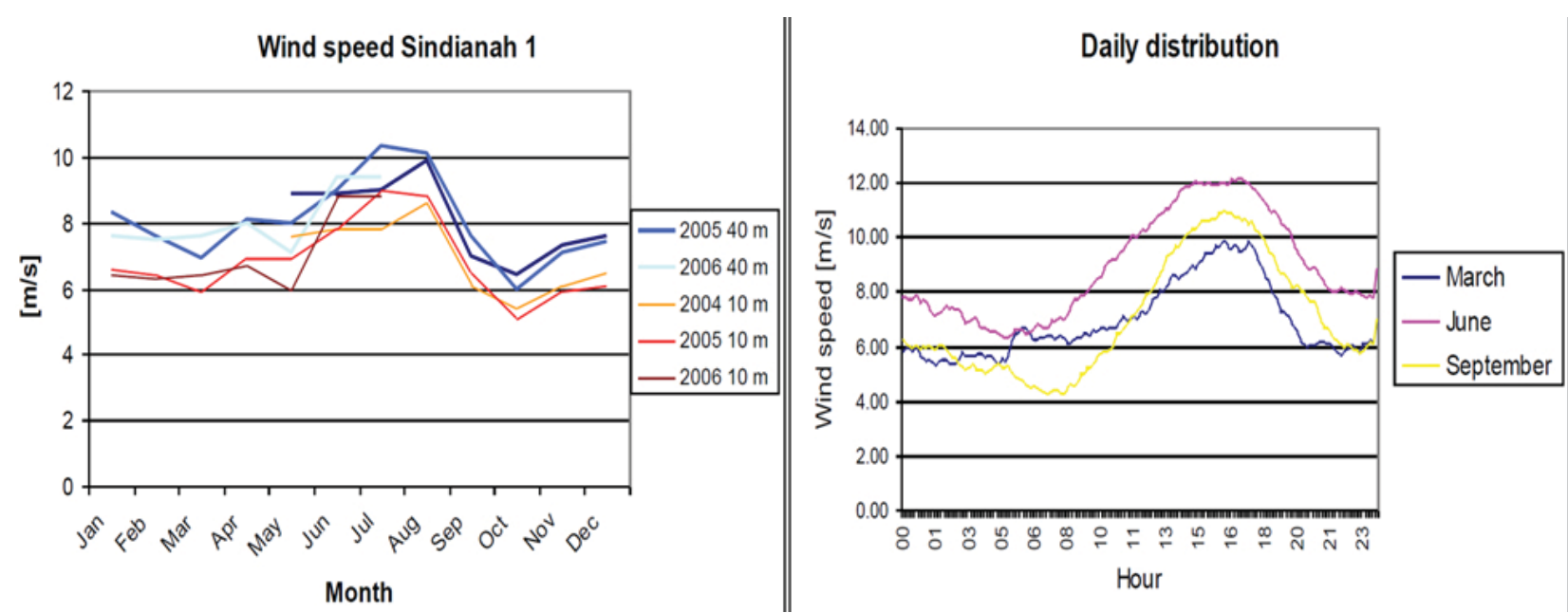

Figure 2: Annual and daily wind speed distributions in Sindianah 1 [09] 
Table 1: Promising wind sites in Syria [08]

\begin{tabular}{|c|c|c|c|c|c|}
\hline Site & Area & Location & Altitude [m] & $\begin{array}{l}\text { Average wind } \\
\text { speed at height } \\
40 \mathrm{~m}[\mathrm{~m} / \mathrm{s}]\end{array}$ & $\begin{array}{c}\text { Max wind speed } \\
\text { at height } 40 \mathrm{~m} \\
{[\mathrm{~m} / \mathrm{s}]}\end{array}$ \\
\hline Sindianah 1 & Homs & E 36²6.4730’ N3442.9101' & 545 & 8 & 23.3 \\
\hline Sindianah 2 & Homs & E $36^{\circ} 26.1635^{\prime} \mathrm{N} 34^{\circ} 42.1377^{\prime}$ & 515 & 8 & 23.3 \\
\hline Nabe Alfoar & Qunitra & E $35^{\circ} 56.68^{\prime}$ N $33^{\circ} 14.04^{\prime}$ & 935 & 6.2 & 23.9 \\
\hline Ghabagheb & Daraa & E $36^{\circ} 15.801^{\prime} N 33^{\circ} 12.30^{\prime}$ & 760 & 6.6 & 23.7 \\
\hline Jandar & Homs & E $36^{\circ} 46.286^{\prime}$ N $34^{\circ} 28.397^{\prime}$ & 750 & 7.7 & 23.3 \\
\hline Hasia & Homs & E 36 47.956' N 34²0.106' & 960 & 6.1 & 24.7 \\
\hline Qutina & Homs & E 36 $36.857^{\prime}$ N 3440.216' & 505 & 7.8 & 24 \\
\hline Ethria & Homs & E $37^{\circ} 49.575^{\prime} N 35^{\circ} 22.163^{\prime}$ & 480 & 6.2 & 24.6 \\
\hline Al-hijana & $\begin{array}{l}\text { Damascus } \\
\text { countryside }\end{array}$ & E $36^{\circ} 41.939^{\prime} N 33^{\circ} 22.637^{\prime}$ & 602 & 6.7 & 25.1 \\
\hline Al-Hara & Daraa & E 355 59.371' N 3303.609' & 998 & 7.6 & 22 \\
\hline Edlib & Edlib & E 36³8.981' N 3558.889' & 386 & 6.3 & 21.5 \\
\hline Tias & Homs & E $37^{\circ} 42.421^{\prime} \mathrm{N} 34^{\circ} 32.591^{\prime}$ & 562 & 5.1 & 22.8 \\
\hline Palmyra & Homs & E 38 $14.286^{\prime}$ N 3433.879' & 473 & 6.2 & 22.3 \\
\hline Al-sukhna & Homs & E $38^{\circ} 49.86^{\prime}$ N $34^{\circ} 52.175^{\prime}$ & 537 & 7.2 & 24.2 \\
\hline Thawra & Raqaa & E $38^{\circ} 30.44^{\prime}$ N $35^{\circ} 48.63^{\prime}$ & 360 & 6.3 & 19.91 \\
\hline
\end{tabular}

\section{CALCULATION METHOD OF AVERAGE TOTAL GROSS AND TECHNICAL POTENTIAL OF SOLAR RESOURCES}

Calculation method was developed to calculate the average total gross and technical potential of solar energy falling on a horizontal surface for any suitable area (Syria is our study case). This method is based on the electronic resource (Solar Atlas of the Mediterranean) and Google Earth program. The electronic resource (Solar Atlas of the Mediterranean) is used to know the global horizontal irradiance GHI of a particular area (Syria). The program Google Earth is used to create zones, which characterized by the corresponding average value of global horizontal irradiance, and also to calculate the zone area. The method was divided into three stages (1. Input data, 2. Zonation, 3. Calculation of energy potential) (see Figure 3 ), and each stage is described below.

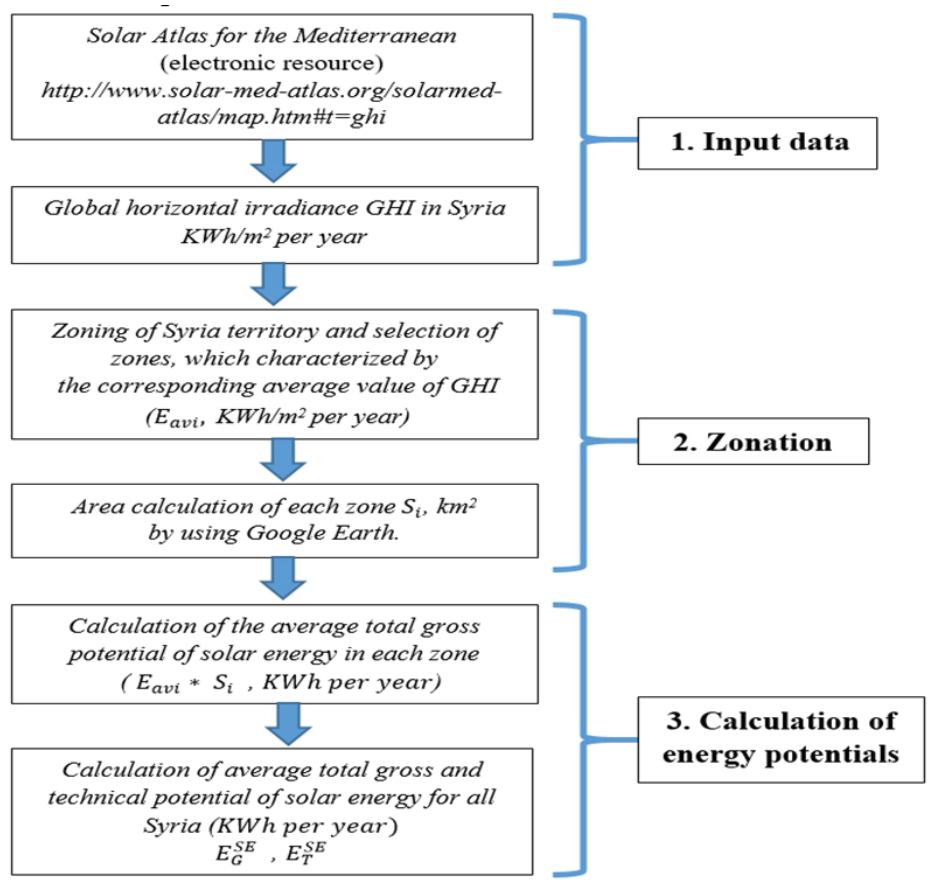

Figure 3: Calculation method of average total gross and technical potential of solar resources 


\section{Input data}

Map of solar energy falling on a horizontal surface (global horizontal irradiance $\mathrm{GHI}$ ) of Syria was taken from electronic resource (Solar Atlas of the Mediterranean) (see Figure 4). The "Solar Atlas for the Mediterranean" is a portal for global horizontal and direct normal irradi- ance data for the southern and eastern Mediterranean region. The atlas has high resolution $(1 \mathrm{~km})$ and long term coverage 20 years (1991-2010) data on the available resources for the whole target region covering the countries: Syria, Jordan, Israel, Lebanon, Egypt, Libya, Tunisia, Algeria, Morocco, Palestine National Authority, Mauretania and Turkey [10].

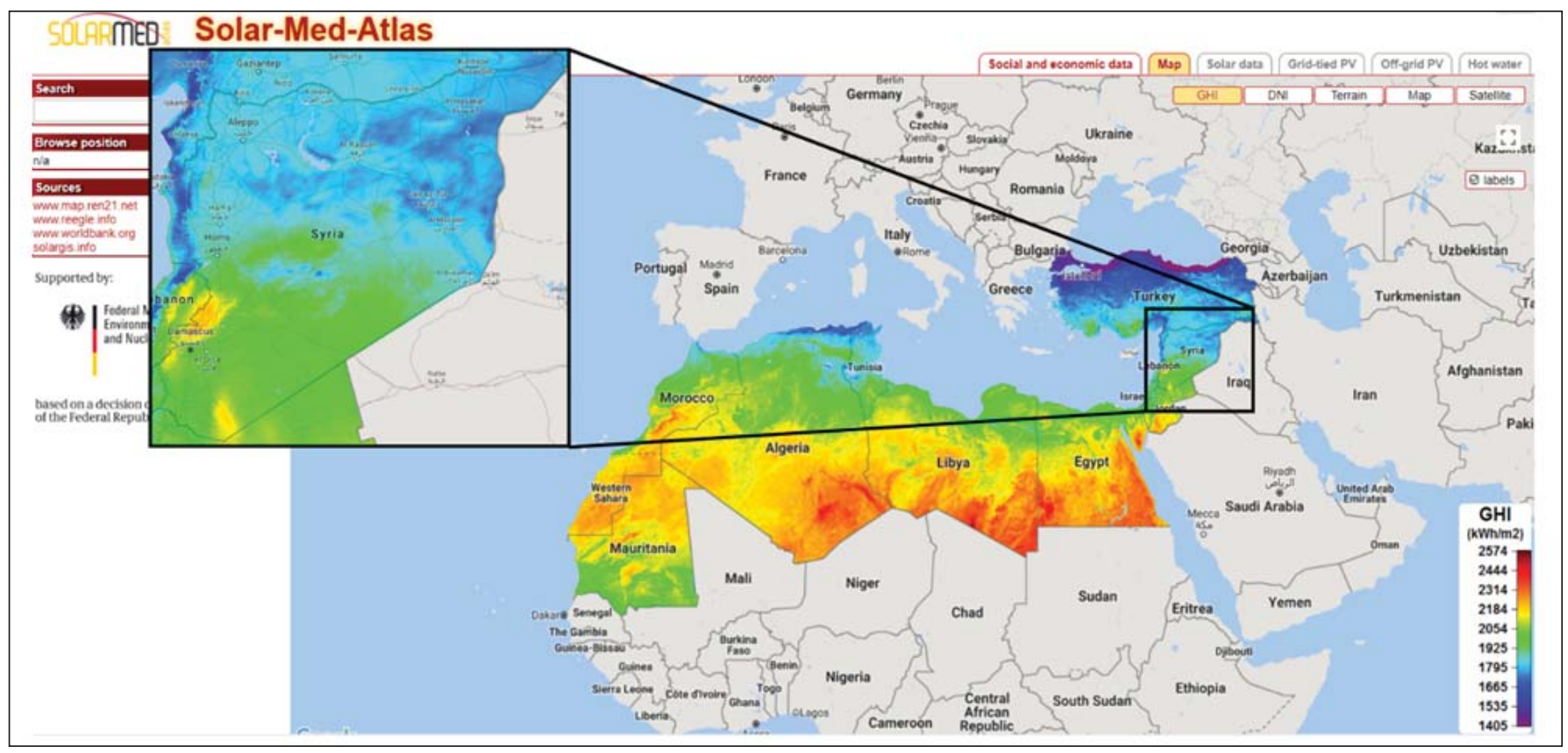

Figure 4: Solar Atlas for the Mediterranean (global horizontal irradiance $\mathrm{GHI}, \mathrm{KWh} / \mathrm{m}^{2} / \mathrm{year}$ )

\section{Zonation}

Map of Syria, which was taken from "Solar Atlas for the Mediterranean", was inserted in Google Earth program [11]. Zoning of the Syria territory was carried out using tools of Google Earth program and the country was di- vided into five zones, which characterized by the corresponding average value of solar energy falling on a horizontal surface [KWh/m²/year] (see Figure 5). The tools of Google Earth program were used to calculate the area of each zone.

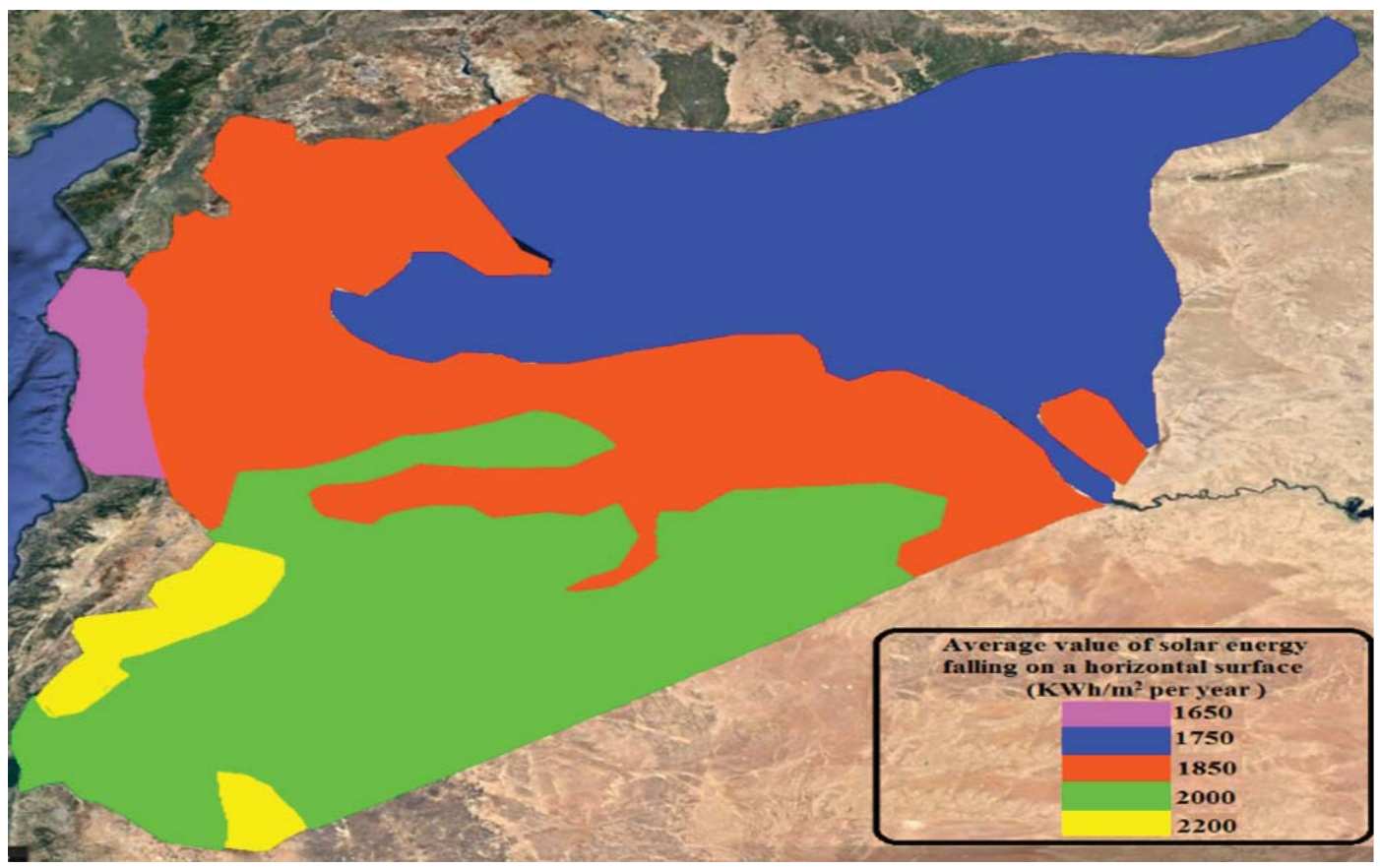

Figure 5: The average value of solar energy falling on a horizontal surface [KWh/m² /year] 


\section{Calculation of energy potentials}

$\left.S_{\mathrm{i}}\right)$ [kwh/year] is calculated (see Table 2).

In this stage, the average total gross potential of solar energy falling on a horizontal surface in each zone $\mathrm{E}_{\text {avi }}{ }^{*}$

Table 2: The average total gross potential of solar energy on a horizontal surface in each zone

\begin{tabular}{|c|c|c|c|}
\hline Zone & $\mathbf{E}_{\text {avi }} \mathbf{k w h / \mathbf { m } ^ { 2 } \text { per year }}$ & Area of Zone $\mathbf{k m}^{2} \mathbf{S}_{\mathbf{i}}$ & $\mathbf{E}_{\text {avi }}{ }^{*} \mathbf{S}_{\mathbf{i}} \mathbf{G W h} /$ year \\
\hline zone 1 & 1650 & 4847 & 7997550 \\
\hline zone 2 & 1750 & 63574 & 111254500 \\
\hline zone 3 & 1850 & 56710 & 104913500 \\
\hline zone 4 & 2000 & 54335 & 108670000 \\
\hline zone 5 & 2200 & 5714 & 12570800 \\
\hline
\end{tabular}

The average total gross potential of solar energy on a horizontal surface for all Syria is calculated by the equation:

$$
E_{G}^{S E}=\sum E_{a v i} * S_{i} \cong 345406 \mathrm{TWh} / \text { year }
$$

When using solar panels with average efficiency equal to $16 \%\left(\eta_{s p}=16 \%\right)$, the average technical potential of solar energy on a horizontal surface for all Syria $E_{T}{ }_{T} E$ is given by [12]:

$$
\left.E_{T}^{S E}=E_{G}^{S E} * \eta_{s p}=345406 * 0.16=55265 \mathrm{TWh} / \text { year } 2\right)
$$

\section{CALCULATION METHOD OF AVERAGE TOTAL GROSS AND TECHNICAL POTENTIAL OF WIND RESOURCES}

The other calculation method was developed for calculating the average total gross and technical potential of wind resources in any particular area (Syria is our study case). It is similar to the previous method in principle and using the Google Earth program, but the difference here is the electronic resource. The electronic resource (Global Wind Atlas) is used to know the wind power density of a particular area (Syria). The method was also divided into three stages (1. Input data, 2. Zonation, 3. Calculation of energy potential), and each stage is described below. The whole method is shown in Figure 6.

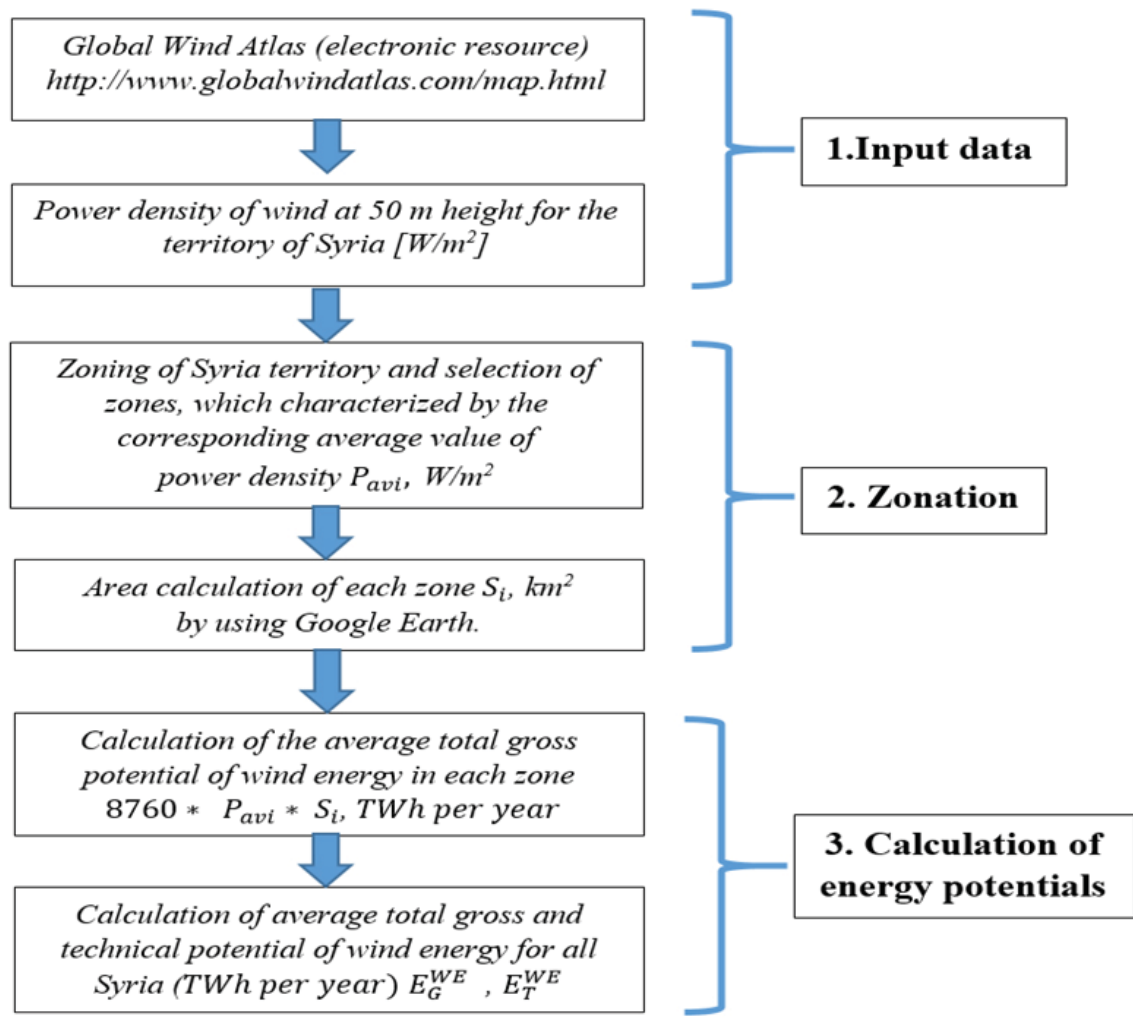

Figure 6: Calculation method of average total gross and technical potential of wind resources 


\section{Input data}

The map of power density of wind $\mathrm{W} / \mathrm{m} 2$ in Syria at height $50 \mathrm{~m}$ was taken from electronic resource (Global Wind Atlas) (see Figure 7). The Global Wind Atlas is part of an international collaboration, it provides wind resource data accounting for high resolution effects $(1 \mathrm{~km})$. The correct usage of the Global Wind Atlas dataset and tools is for aggregation, upscaling analysis and energy integration modelling for energy planners and policy makers. It is not correct to use the data and tools for wind farm siting [13].

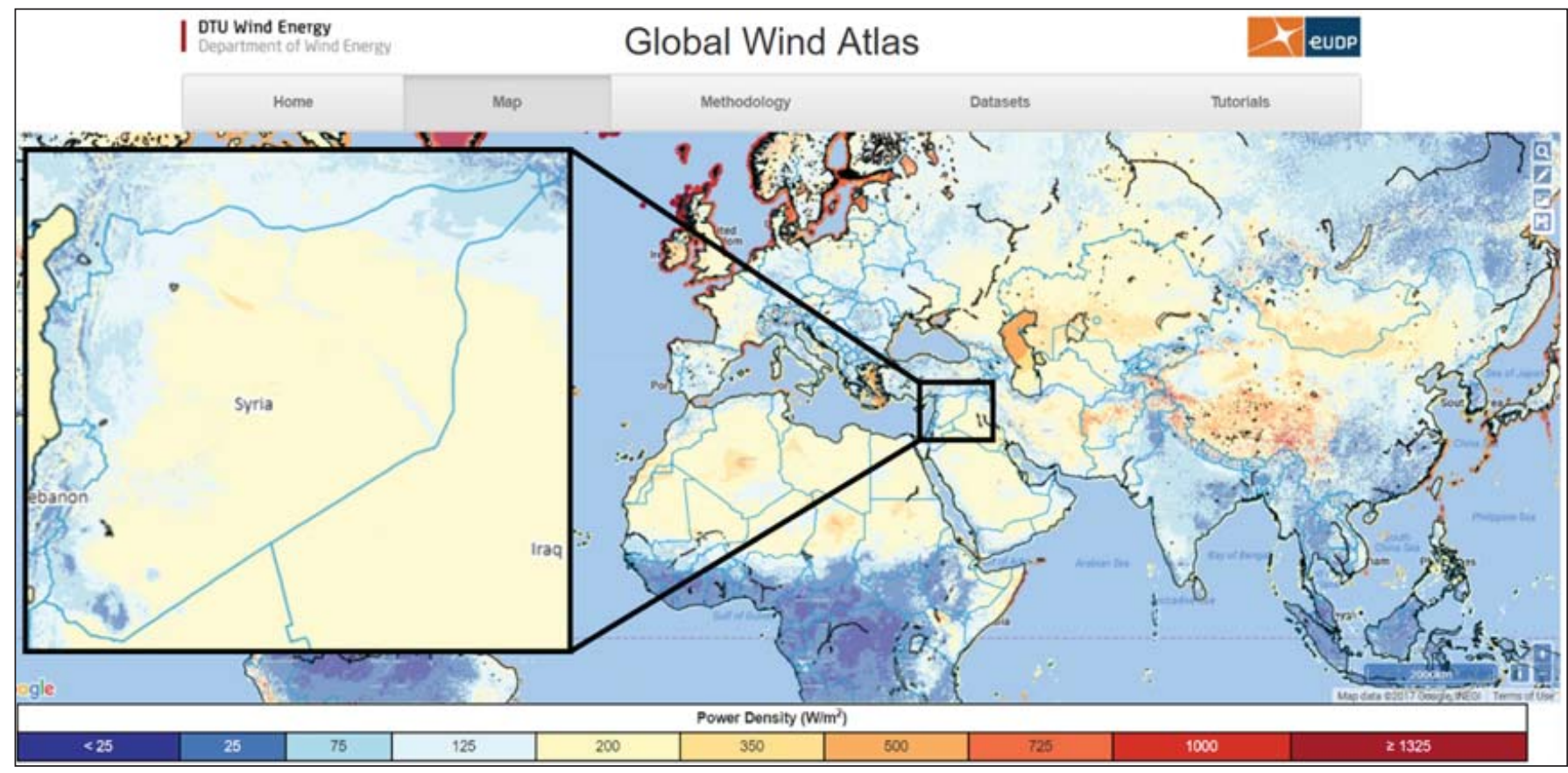

Figure 7: Global Wind Atlas (power density of wind [W/m²] at 50m height)

The data used in the Global Wind Atlas was chosen from the best available global datasets for each required category. A reanalysis is a scientific method for developing a comprehensive record of how weather and climate are changing over time. In a reanalysis observations around the globe and a numerical weather prediction model, which simulates one or more aspects of Earth system, are combined objectively to generate a synthesized estimate of the state of the system. In the $2010^{\text {s }}$ four large atmospheric reanalysis projects took place. These are listed in table 3 . All provide output at a horizontal resolution below $1^{\circ} \times 1^{\circ}$. Three of these reanalysis (i.e., CFDDA, CFSR and MERRA) were generalized and later used in the global wind atlas. Global Wind Atlas begins with large scale wind climate data and end with micro scale wind climate data. The large scale wind climate data is pro- vided by atmospheric reanalysis data, from meteorological centers around the world. These data are on a grid with spacing of about $50 \mathrm{~km}$ depending on the dataset. A generalization process on this data was carried out. The result is a set of generalized wind climates which have the same spacing as the reanalysis data that was used to create them [13]. Next Global Wind Atlas takes this set of generalized wind climates and apply them in the microscale modelling system over the globe (apart from the poles and far offshore ocean areas). The modelling process is composed of a calculation for the local wind climates every $250 \mathrm{~m}$ at three heights, 50, 100 and 200 $\mathrm{m}$. So on a $250 \mathrm{~m}$ grid, there is a local wind climate estimation. Local wind climate characteristics are aggregated up to a $1 \mathrm{~km}$ grid.

Table 3: Characteristics of the global reanalysis data used for generating the Global Wind Atlas

\begin{tabular}{|l|c|}
\hline Global reanalysis & Available resolution \\
\hline Climate Forecasting System Reanalysis (CFSR) & $0.5^{\circ} \times 0.5^{\circ} 6 \mathrm{hours}^{\circ}$ \\
\hline $\begin{array}{l}\text { Climate Four Dimensional Data Assimilation } \\
\text { (CFDDA) }\end{array}$ & $0.4^{\circ} \times 0.4^{\circ} 6$ hourly \\
\hline Modern Era-Retrospective Analysis for Research and Applications (MERRA) & $1 / 2^{\circ} \times 2 / 3^{\circ} 6$ hours \\
\hline $\begin{array}{l}\text { European Center for Medium Range Weather Forecast (ECMWF) Reanalysis } \\
\text { (ERA-Interim) }\end{array}$ & $0.71^{\circ} \times 0.71^{\circ} 6$ hours \\
\hline
\end{tabular}




\section{Zonation}

Map of Syria, which was taken from "Global Wind Atlas

", was inserted in Google Earth program. Zoning of the Syria territory was carried out using tools of Google Earth program and the country was divided into seven zones, which characterized by the corresponding average value of wind power density at the height $50 \mathrm{~m}\left(\mathrm{P}_{\text {avi }}\left[\mathrm{W} / \mathrm{m}^{2}\right]\right)$ (see Figure 8). The tools of Google Earth program were used also for calculating the area for each zone .

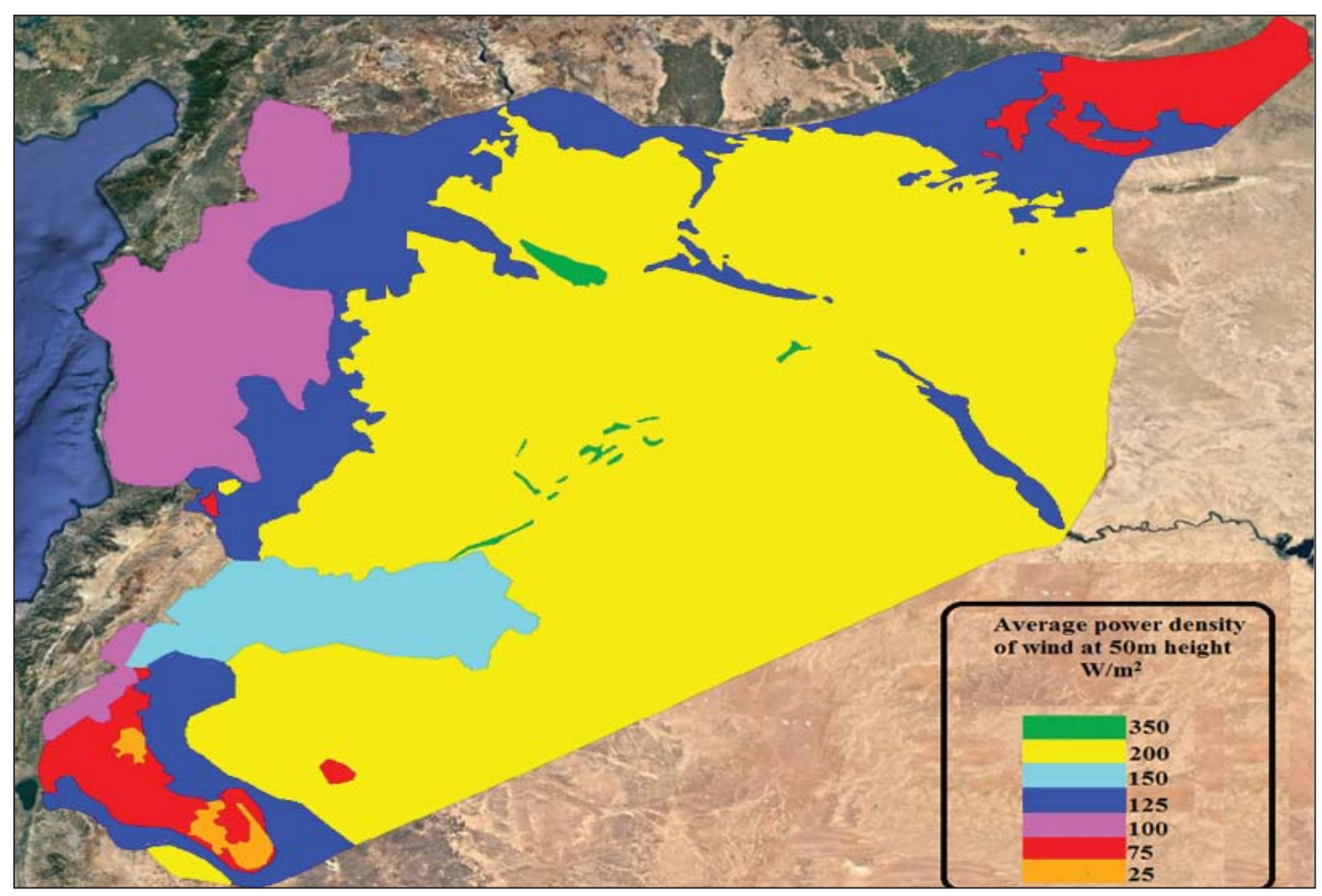

Figure 8: Average power density of wind $P_{\text {avi? }}, W / \mathrm{m}^{2}$ at $50 \mathrm{~m}$ height

\section{Calculation of energy potentials}

In this stage, the average total gross potential of wind energy in each zone ( $E_{\text {avi, }}$, TWh/year ) is calculated by the formula:

$$
E_{\text {avi G }}=P_{\text {avi }} * S_{i} * 8760
$$

Table 4: The average total gross potential of wind energy in each zone at height $50 \mathrm{~m}$

\begin{tabular}{|c|c|c|c|c|}
\hline Zone & $\mathbf{P}_{\text {avi }} \mathbf{W} / \mathbf{m}^{2}$ & $\mathbf{S}_{\mathbf{i}} \mathbf{k m}^{2}$ & $\mathbf{P}_{\text {avi }}{ }^{*} \mathbf{S}_{\mathbf{i}} \mathbf{M W}$ & $\mathbf{E}_{\text {avi, }}, \mathbf{T W h} / \mathbf{y e a r}$ \\
\hline zone 1 & 25 & 1184 & 29600 & 259 \\
\hline zone 2 & 75 & 10869 & 815175 & 7141 \\
\hline zone 3 & 100 & 16644 & 1664400 & 14580 \\
\hline zone 4 & 125 & 30272 & 3784000 & 33148 \\
\hline zone 5 & 150 & 8786 & 1317900 & 11545 \\
\hline zone 6 & 200 & 116564 & 23312800 & 204220 \\
\hline zone 7 & 350 & 861 & 301350 & 2640 \\
\hline
\end{tabular}

The average total power of the wind flow $\mathrm{P}_{\mathrm{G}}$ and the av- at height $50 \mathrm{~m}$ are defined by the formulas: erage total gross potential of wind energy in Syria $E_{G}{ }^{W E}$

Table 4 shows the calculation results of average total gross potential of wind energy in each zone at height $50 \mathrm{~m}$.

$$
\begin{gathered}
P_{G}=\sum P_{\text {avi }} * S_{i}=31225225 \mathrm{MW} \cong 31.2 \mathrm{TW} \\
E_{G}^{W E}=\sum E_{\text {avi } G}=8760 * \sum P_{\text {avi }} * S_{i}=273533 \mathrm{TWh} / \text { year }
\end{gathered}
$$


For calculating the technical potential of wind energy in particular area, following assumptions were considered [14]:

- A wind farm array spacing of $10 \mathrm{~d}$ x $10 \mathrm{~d}$ was used for the calculations. $d$ : rotor diameter of wind turbine.

- Constant wind turbine efficiency $\eta_{w t}$ :

$$
\eta_{\mathrm{wt}}=\mathrm{C}_{\mathrm{p}} * \eta_{\operatorname{mec}} * \eta_{\mathrm{ele}} \approx 0.3
$$

$\mathrm{C}_{\mathrm{p}}$ : Performance coefficient of wind turbine, $\eta_{\operatorname{mec}}:$ mechanical efficiency, $\eta_{\text {ele }}$ electrical efficiency

Available area to create wind farms is the proportion $q$ of the total area.

Thus the technical potential of wind energy in particular area is defined by the formula [14]:

$$
\begin{array}{r}
\frac{\text { Technical wind potential }}{\text { Total gross wind potential }}=\frac{\pi * \eta_{w t} * q * 40}{8 * 100}=\frac{3.14 * 0.3 * q * 40}{8 * 100} \\
=0.0471 * q
\end{array}
$$

As a result the average technical potential of wind energy in each zone of Syria can be defined by the formula:

$$
E_{\text {aviT }}=E_{\text {avi.G }} * 0.0471 * q
$$

For different values of $q$, the average technical potential of wind energy in each zone of Syria and the average total technical potential of wind energy in all Syria at the height $50 \mathrm{~m}$ are shown in Table 5.

The average technical potential of wind energy in all Syria can be defined by the formula:

$$
E_{T}^{W E}=\Sigma E_{\text {avi.T }}
$$

\begin{tabular}{|c|c|c|c|c|c|c|}
\hline $\begin{array}{l}\text { Average technical } \\
\text { wind potential }\end{array}$ & $q$ & $1 \%$ & $2 \%$ & $3 \%$ & $4 \%$ & $5 \%$ \\
\hline$E_{a v 1, T}$ & & 0.1 & 0.2 & 0.4 & 0.9 & 0.6 \\
\hline$E_{a v 2, T}$ & & 3.4 & 6.7 & 10.1 & 13.4 & 16.8 \\
\hline$E_{a v 3, T}$ & & 6.9 & 13.7 & 20.6 & 27.5 & 34.3 \\
\hline$E_{a v 4, T}$ & & 15.6 & 31.2 & 46.8 & 62.4 & 78.1 \\
\hline$E_{a v 5, T}$ & & 5.4 & 10.9 & 16.3 & 21.7 & 27.2 \\
\hline$E_{a v 6, T}$ & & 96.2 & 192.4 & 288.6 & 384.7 & 480.9 \\
\hline$E_{a v 7, T}$ & & 1.2 & 2.5 & 2.5 & 5.0 & 6.2 \\
\hline$E_{T}^{W E}$ & & 129 & 258 & 387 & 516 & 644 \\
\hline
\end{tabular}

Table 5: The average total technical potential of wind energy in each zone and in all Syria at height $50 \mathrm{~m}$ in [TWh /year]

Table 5 illustrates that technical wind energy increases as a result of an increase in available area, which is $q \%$ of the total area, to create wind farms. In addition, selection of $q \%$ in each zone related to: percentage of land used (populated area), distance between wind farm and electrical grid, difficulty of construction (terrain of area). In general, by using $1 \%, 2 \%, 3 \%, 4 \%, 5 \%$ of the total area of Syria, the average technical potential of wind energy is, respectively, $129,258,387,516,644$ TWh lyear.

\section{CONCLUSION}

The two calculation methods were carried out for estimating the average total gross and technical potential of wind and solar resources using electronic resources (Solar Atlas for the Mediterranean, Global Wind Atlas). These methods were applied in Syria as an example and they can also be used in other areas and/or countries for large scaling analysis and estimating the average energy PV and wind potential. Results of analysis methods show that:

The average total gross and technical potential of solar energy on a horizontal surface in Syria were estimated, respectively, 345406 TWh/year and 55265 TWh/year. 
The average power of wind flow at the height of $50 \mathrm{~m}$ and the average total gross potential of wind energy in Syria were estimated, respectively, 31,2 TW and 273533 TWh /year. The average technical potential of wind energy using $1 \%, 2 \%, 3 \%, 4 \%, 5 \%$ of the total area of Syria was estimated, respectively, 129 , $258,387,516,644$ TWh /year.

\section{ACKNOWLEDGMENTS}

The authors acknowledge the support of Research and Education Centre "Renewable Energy sources and Their Application in Power Plants" and Peter the Great Saint-Petersburg Polytechnic University, St. Petersburg, Russia.

\section{REFERENCES}

1. International Energy Agency (IEA), Key world energy statistics, from https://www.iea.org/publications/ freepublications/publication/KeyWorld2017.pdf, accessed 1 November 2017.

2. Elistratov, V. (2017). Current situation and trends of the world RES development. International Scientific Journal for Alternative Energy and Ecology, No. 1-3, pp. 84-100. [in Russian]

3. International Renewable Energy Agency (IRENA), Renewable capacity statistics 2017, from http:// www.irena.org/DocumentDownloads/Publications/ IRENA_Renewable_Energy_Statistics_2017.pdf, accessed 1 November 2017.

4. REN21, Renewables 2017 Global Status Report, from http://www.ren21.net/wp-content/uploads/2017/06/17- 8399_GSR_2017_Full_Report_0621_Opt.pdf, accessed 1 November $201 \overline{7}$.

5. Ramadan, A., Elistratov, V., (2017). ispol'zovaniye vozobnovlyayemykh istochnikov energii v sirii (Use of renewable energy sources in Syria). Fifth Int. Conf. Vozobnovlyayemaya energetika: problemy i perspektivy, Makhachkala, Russia, pp. 135-141. [in Russian]

6. Ramadan, A., (2016). Issledovaniye i raschot parametrov vetroelektrostantsii dlya usloviy Sirii (Study and calculation of wind power plant parameters for Syria conditions). Master thesis, Saint Petersburg, Peter the Great Saint Petersburg Polytechnic University, 110p. [in Russian]

7. Hamzeh, A., (2004). Overview of THE Syrian Energy Profile. Paper submitted to Regional Collaboration Workshop on Energy Efficiency and Renewable Energy Technology, Beirut, Lebanon, 17p.

8. Meed projects. Mena renewable energy 2012 report sample - Syria, from http://ezine.meed. com/MEED-Insight-Mena-Renewable-Energy-2012-Sample/, accessed 1 November 2017.

9. Wind resource assessment for Syrian Arab Republic. Wind data evaluation and pre-feasibility study sindianah 1, from http://www.nerc.gov.sy/images/
wind/wind-pdf/Sindianah1.pdf, accessed 1 November 2017.

10. Solar Atlas for the Mediterranean, from http://www. solar-med-atlas.org/solarmed-atlas/solar_data, accessed 1 July 2017.

11. Google Earth Outreach Training. Workbook for Indigenous Mapping Workshop, from www.grenadinesmarsis.com/uploads/Guide_GoogleEarthMaps_Training.pdf, accessed 1 July 2017.

12. Vissarionov, V., Deryugina, G., Kuznetsova, V., Malinin, N. (2008). Solnechnaya energetika (Solar Energy). Moscow Power Engineering Institute Press, 320p. [in Russian]

13. Global Wind Atlas, from http://www.globalwindatlas. com/map.html, accessed 1 July 2017.

14. Vasiliev, Yu., Bezrukhikh, P., Elistratov, V., Sidorenko, G. (2008). Otsenki resursov vozobnovlyayemykh istochnikov energii $v$ Rossii (Assessments of Renewable Energy Resources in Russia). Polytechnic University Press, St. Petersburg, 251p. [in Russian]
Paper submitted: 16.12.2017.

Paper accepted: 14.03.2018.

This is an open access article distributed under the CC BY-NC-ND 4.0 terms and conditions. 